\title{
Experimental research on characteristics of hole reaming and side cutting of one-cone bits
}

\author{
Yu Kai’an* \\ School of Mechanical and Electronic Engineering, China University of Petroleum, Beijing 102249, China
}

\begin{abstract}
The hole reaming and side cutting characteristics of offset one-cone bit and conventional onecone bit were investigated on simulated drilling experimental equipment. The borehole diameter was a little larger than the bit diameter due to side force. However, the reaming effect was not very apparent, whether drilling with an offset or conventional one-cone bit. The side cutting displacement increased gradually with increasing depth of drilling and side force. The side cutting displacement of offset onecone bits was larger than that of conventional ones under the same conditions of weight-on-bit (WOB), rotary speed, side force and borehole depth.
\end{abstract}

Key words: Offset one-cone bit, conventional one-cone bit, hole reaming, side cutting

\section{Introduction}

Since the 1990s, slim hole drilling technology has been the focus of research for new drilling technology (Fletcher, 2003; Langford Jr, 1999; Li and Tan, 2000; Qiu, 2000; Wu and Liu, 2000). Slim hole drilling can significantly reduce drilling cost, and is beneficial to the exploration of deep formations, the development of low-permeability reservoirs, old wells drilled deeper (OWDD) and side tracking in old wells. The application of modern slim hole drilling technology brings some new requirements for bits.

Because of limited annular space, a series of problems, such as higher annular pressure loss, lower bottom hole hydraulic energy, increasing possibility of drill pipe sticking, often occur during drilling or cementing. Besides, a good cement job can not be achieved. The usual treatment is to use offset bits to achieve reamed holes in oil-bearing formations and complex formations. Because they facilitate miniaturization, one-cone bits can be used in slim hole drilling. It is necessary to investigate whether the one-cone bit has reaming ability during drilling.

With the rapidly increasing workload of large deflection rate and long horizontal section in slim hole drilling, smallsize bits with strong side cutting ability and better effect of building angle are required. At present, PDC offset bits are used to improve the ability of building angle. However, PDC bits are sensitive to formations, they are not applicable to drilling in the formation having multiple intercalated beds. In addition, PDC bits will cause excessive moment of resistance in drilling, which can destroy the small-size motor, resulting in frequent tripping operations and increasing expense of replacing motors. The offset one-cone bit is a type of roller

* Corresponding author. email: kaianyu@163.com Received August 22, 2007 bit, and it is not formation-sensitive. Therefore, offset onecone bits can be used to drill complex formations where PDC bits cannot be used. Besides, the moment of resistance on an offset one-cone bit is lower than that on a PDC bit, thereby extending the life of small-size downhole motor. Several researchers have studied and designed one-cone bits (Bulatov, 1965; Chen, 2008; Deng et al, 2001; Ma et al, 2004; Moran and Witman, Xia et al, 2002; Witman et al, 2006; Yu and $\mathrm{Yu}, 2007)$, but their side cutting ability is still an issue to be studied.

\section{Experimental equipment and test method}

The experimental equipment was composed of a drilling rig, mud circulation system, core-holding unit, lateral force loading system and data acquisition system.

The drilling rig was an XY-4 type engineering geological drilling rig, and its schematic diagram is shown in Fig. 1. The drilling rig was driven by a $30 \mathrm{~kW}$ motor (motor 1 ). The rotary speed of the kelly bar was controlled at 100-1200 r/min by adjusting a gear box and a transfer case. The horizontal rotary motion provided by motor 1 was converted into vertical rotary motion of kelly bar conductor 10 and kelly bar 12 through bevel gears 8 and 9. Chuck 6 was connected with cross beam 7 . With the motion of piston rod of hydraulic cylinder 11 , the kelly bar was lowered or raised and axial loading was applied on the kelly bar. The maximum stroke, weight on bit (WOB) and hoisting capacity of the kelly bar were $600 \mathrm{~mm}, 60 \mathrm{kN}$ and $80 \mathrm{kN}$, respectively.

The mud circulation system included a pump, a water tank and manifold.

The schematic diagram of core holding unit, hydraulic loading system (lateral force) and data acquisition system is shown in Fig. 2.

The core-holding unit includes rock sample box 1, rolling device 11 fixed on rock sample box and braking device of 


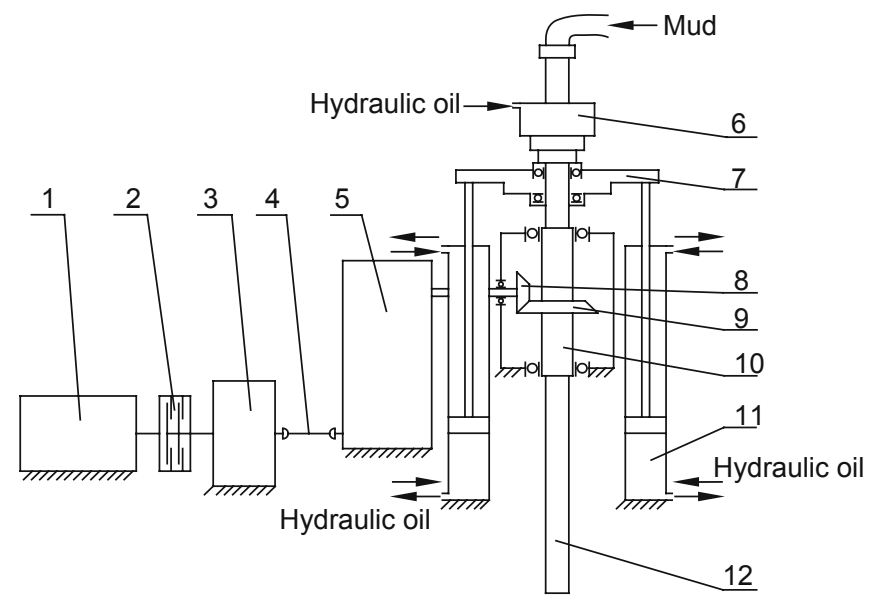

Fig. 1 Schematic diagram of XY-4 type drilling rig 1-30 kW electric motor; 2-Clutch; 3-Gear box; 4-Universal shaft; 5-Transfer case; 6-Chuck; 7-Cross beam; 8, 9-Bevel gear; 10-Kelly bar conductor; 11- Hydraulic cylinder; 12-Kelly bar

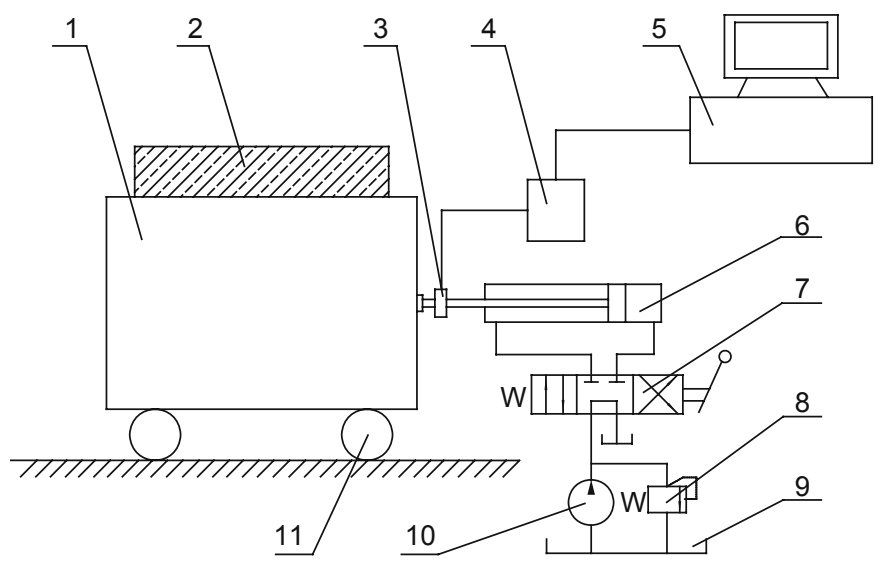

Fig. 2 Schematic diagram of core-holding unit, hydraulic system and data acquisition system

1-Rock sample box; 2-Core sample (rock sample); 3-Pressure transducer; 4-Digital voltmeter; 5-Computer; 6-Hydraulic cylinder; 7-Reversing valve; 8-Overflow valve; 9-Oil tank; 10-Hydraulic pump; 11-Roller device of rock box

the roller. The braking device locked the rolling device when drilling perpendicularly and was released in the side cutting experiment. The rock box can move on the guide track in the lateral direction through the bottom rolling device.

The loading and unloading of lateral force was achieved by the motion of the piston rod of the hydraulic cylinder.

Data acquisition system was used to measure the lateral force applied on rock sample.

The rotary speed of the kelly bar, which was adjusted by the driving system of drilling rig, was $101 \mathrm{r} / \mathrm{min}$ in this experiment. The weight on bit (WOB) was loaded by a hydraulic cylinder, and the data was acquired with a weight indicator. The side force was measured by the data acquisition system. The diameter of borehole and side cutting displacement can be measured directly.

\section{Analysis of experimental results}

Two types of one-cone bits used in the experiment are shown in Fig. 3. The offset one-cone bit had an offset distance, $d_{\mathrm{s}}$ of $6.5 \mathrm{~mm}$, but the conventional one-cone bit had no offset distance. The journal angles of both bits were $36^{\circ}$ and their diameters were $118 \mathrm{~mm}$ (45/8 in). The rock sample was granite.

Boreholes drilled with conventional one-cone bits are shown in Fig. 4 and boreholes drilled with one-cone bits with an offset distance of $6.5 \mathrm{~mm}$ are shown in Fig. 5.

\subsection{Reaming characteristics of one-cone bits}

Experimental data on side force, borehole depth and borehole diameter when drilling with conventional one-cone bit and the one-cone bit with an offset distance of $6.5 \mathrm{~mm}$ are

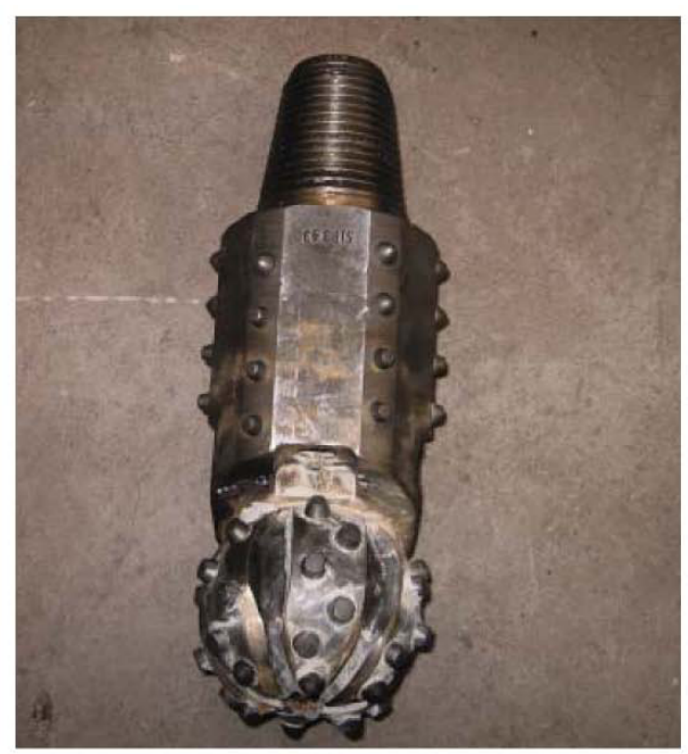

(a) Conventional one-cone bit

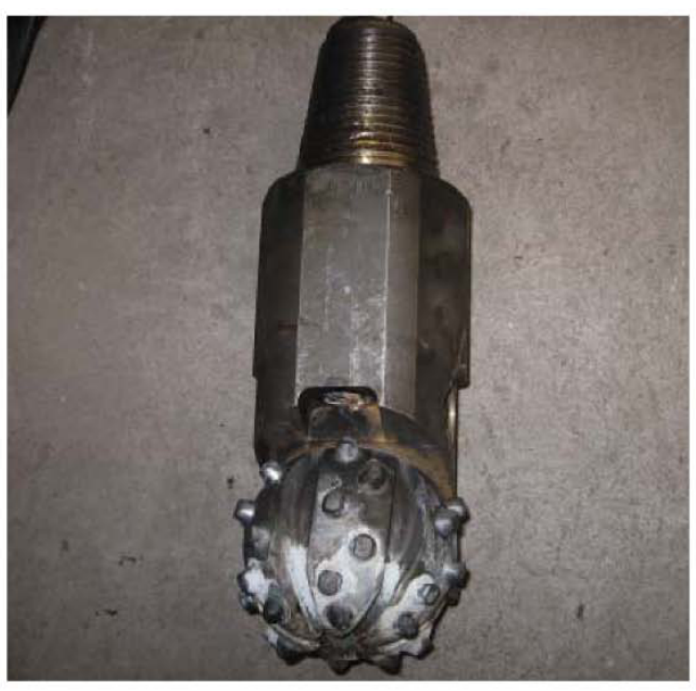

(b) One-cone bit with an offset distance

Fig. 3 Pictures of one-cone bits used 

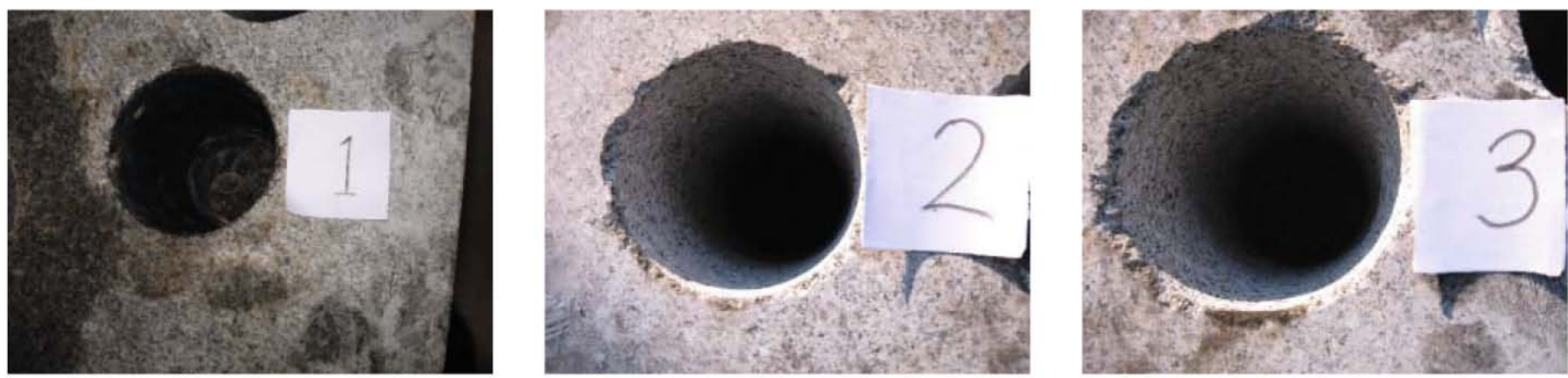

Fig. 4 Boreholes drilled with the conventional one-cone bit
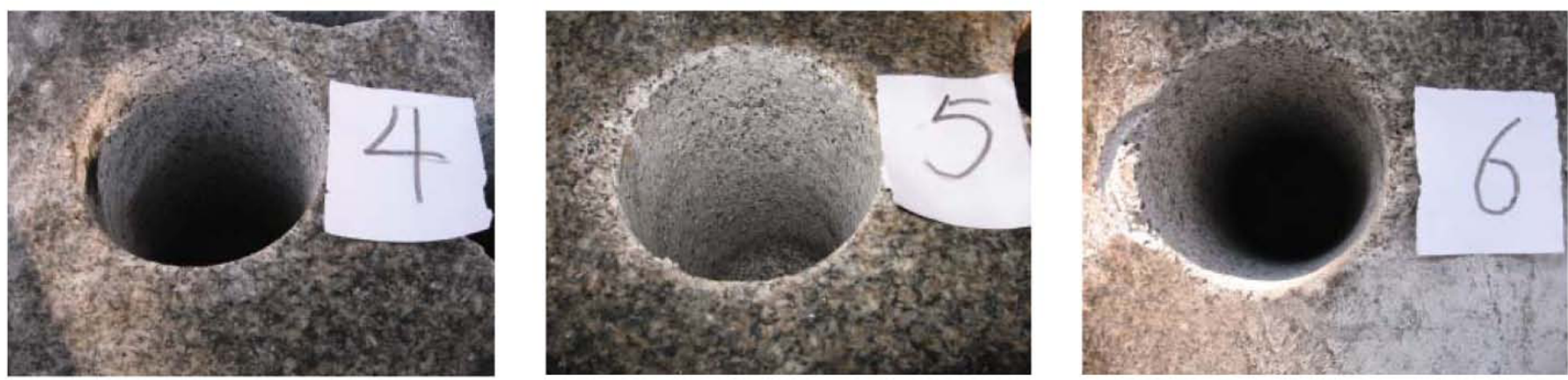

Fig. 5 Boreholes drilled with the one-cone bit with an offset distance of $6.5 \mathrm{~mm}$

listed in Tables 1 and 2, respectively.

Table 1 shows when drilling with the conventional bit, the borehole diameter would be enlarged slightly, a little larger than the bit diameter due to side force. Apparently, the third borehole was elliptical, which was caused by excessive tripping operations because of the failure of drilling equipment.

Table 2 shows that when drilling with the offset one- cone bit, the borehole diameter was a little larger than the bit diameter due to side force, but a reaming effect was not very apparent.

Based on experimental data listed in Tables 1 and 2, both conventional and offset one-cone bits have a slight reaming effect.

The reason was that the drill pipe used was a slender bar, flexible deformation of the pipe would be greater during

Table 1 Data on side force, borehole depth and borehole diameter when drilling with the conventional one-cone bit

\begin{tabular}{ccccccc}
\hline $\begin{array}{c}\text { Borehole } \\
\text { No. }\end{array}$ & $\begin{array}{c}\text { WOB } \\
\mathrm{kN}\end{array}$ & $\begin{array}{c}\text { Drill pipe rotation } \\
\mathrm{r} / \mathrm{min}\end{array}$ & $\begin{array}{c}\text { Side force } \\
\mathrm{N}\end{array}$ & $\begin{array}{c}\text { Borehole depth } \\
\mathrm{mm}\end{array}$ & $\begin{array}{c}\text { Borehole diameter } \\
\mathrm{mm}\end{array}$ & $\begin{array}{c}\text { Average diameter } \\
\mathrm{mm}\end{array}$ \\
\hline 1 & 29 & 101 & 862 & 265 & $121.0,122.0,120.0,122.5$ & 121.4 \\
2 & 29 & 101 & 911 & 390 & $120.5,121.0,120.5,121.0$ & 120.8 \\
3 & 29 & 101 & 1450 & 320 & $121.0,129.5,130.0,120.0$ & 125.1 \\
\hline
\end{tabular}

Table 2 Data on side force, borehole depth and borehole diameter when drilling with the offset one-cone bit

\begin{tabular}{ccccccc}
\hline $\begin{array}{c}\text { Borehole } \\
\text { No. }\end{array}$ & $\begin{array}{c}\text { WOB } \\
\mathrm{kN}\end{array}$ & $\begin{array}{c}\text { Drill pipe rotation } \\
\mathrm{r} / \mathrm{min}\end{array}$ & $\begin{array}{c}\text { Side force } \\
\mathrm{N}\end{array}$ & $\begin{array}{c}\text { Borehole depth } \\
\mathrm{mm}\end{array}$ & $\begin{array}{c}\text { Borehole diameter } \\
\mathrm{mm}\end{array}$ & $\begin{array}{c}\text { Average diameter } \\
\mathrm{mm}\end{array}$ \\
\hline 4 & 21 & 101 & 951 & 354 & $119.0,120.0,119.5,120.5$ & 119.8 \\
5 & 29 & 101 & 1441 & 337 & $118.5,120.0,118.5,119.0$ & 119.0 \\
6 & 29 & 101 & 1480 & 360 & $120.5,119.5,118.5,119.5$ & 119.5 \\
\hline
\end{tabular}


drilling. However, the rocks around the borehole had high stiffness, the bit was restricted to drill along the center of the borehole after drilling into the rock.

\subsection{Side cutting characteristics of one-cone bits}

Experimental data on side force, borehole depth and side cutting displacement during drilling with the conventional one-cone bit and the offset one-cone bit are shown in Tables 3 and 4 , respectively.

Experimental data in Tables 3 and 4 indicate that the side cutting displacement increased gradually with increasing depth of drilling and increasing side force. The displacement of side cutting in No. 3 borehole was great because of the frequent tripping caused by drilling equipment failure. The side cutting displacement of offset one-cone bit was larger than that of conventional one-cone bit under the condition of near the same side force (for instance, $911 \mathrm{~N}$ in Table 3 and $951 \mathrm{~N}$ in Table 4) and same borehole depth. This shows that the offset one-cone bit has stronger side cutting ability than the conventional one-cone bit.

Table 3 Measured data on side force, borehole depth and side cutting displacement when drilling with the conventional one-cone bit

\begin{tabular}{|c|c|c|c|c|c|}
\hline Borehole No. & $\begin{array}{l}\text { WOB } \\
\mathrm{kN}\end{array}$ & $\begin{array}{l}\text { Drill pipe rotation } \\
\mathrm{r} / \mathrm{min}\end{array}$ & $\begin{array}{l}\text { Side force } \\
\mathrm{N}\end{array}$ & $\begin{array}{l}\text { Borehole depth } \\
\mathrm{mm}\end{array}$ & $\begin{array}{l}\text { Side cutting displacement } \\
\mathrm{mm}\end{array}$ \\
\hline & & & & 80 & 0 \\
\hline \multirow[t]{3}{*}{1} & 29 & 101 & 862 & 150 & 0.6 \\
\hline & & & & 200 & 1.0 \\
\hline & & & & 90 & 1.5 \\
\hline \multirow[t]{3}{*}{2} & 29 & 101 & 911 & 180 & 2.5 \\
\hline & & & & 270 & 4.0 \\
\hline & & & & 90 & 6.0 \\
\hline \multirow[t]{2}{*}{3} & 29 & 101 & 1450 & 180 & 8.0 \\
\hline & & & & 270 & 9.2 \\
\hline
\end{tabular}

Table 4 Measured data on side force, borehole depth and side cutting displacement when drilling with the offset one-cone bit

\begin{tabular}{|c|c|c|c|c|c|}
\hline Borehole No. & $\begin{array}{l}\text { WOB } \\
\mathrm{kN}\end{array}$ & $\begin{array}{l}\text { Drill pipe rotation } \\
\mathrm{r} / \mathrm{min}\end{array}$ & $\begin{array}{c}\text { Side force } \\
\mathrm{N}\end{array}$ & $\begin{array}{l}\text { Borehole depth } \\
\mathrm{mm}\end{array}$ & $\begin{array}{l}\text { Side cutting displacement } \\
\mathrm{mm}\end{array}$ \\
\hline & & & & 90 & 2.2 \\
\hline \multirow[t]{3}{*}{4} & 21 & 101 & 951 & 180 & 4.0 \\
\hline & & & & 270 & 6.0 \\
\hline & & & & 90 & 2.0 \\
\hline \multirow[t]{3}{*}{5} & 29 & 101 & 1441 & 180 & 5.5 \\
\hline & & & & 270 & 8.0 \\
\hline & & & & 90 & 4.0 \\
\hline \multirow[t]{2}{*}{6} & 29 & 101 & 1480 & 180 & 8.0 \\
\hline & & & & 270 & 9.4 \\
\hline
\end{tabular}

\section{Conclusions}

1) Neither the offset one-cone bit nor the conventional one has obvious reaming characteristics when drilling granite. The reaming effect will not be satisfactory if the offset onecone bit is used for reaming holes.

2) The side cutting ability of the offset one-cone bit is stronger than that of the conventional one under the same conditions. The offset one-cone bit pertains to drilling the build section of a well.

\section{References}

Bulatov V V. Kinematics of a one-cone drilling bit. Journal of Mining Science. 1965. 1(2): 119-128

Chen Y H. Experimental study of rock-breaking with an offset single cone bit. Petroleum Science. 2008. 5(2): 179-182

Deng R, Wang F and Xiong C W. Design and analysis of mono-cone bits. Journal of Sichuan University (Engineering Science Edition). 2001. 33(5): 51-54 (in Chinese)

Fletcher S. Custom designed single-cone bit works for well off Albania. Oil \& Gas Journal. 2003. 101(30): 44-45 
Langford Jr J W. One-cone bits improve efficiency of drilling small diameter holes. Petroleum Engineer International. 1999. 72(2): 23-28

Li J B and Tan A P. The slim hole technology and problems in re-entry in Zhongyuan Oilfield. Drilling \& Production Technology. 2000. 23(1): 9-13 (in Chinese)

Ma H W, Deng R and Sheng Y P. The well-bottom trace analysis of onecone bit. Oil Field Equipment. 2004. 33(5): 41-43 (in Chinese)

Moran D P and Witman IV G B. One cone bit with interchangeable cutting structures, a box-end connection, and integral sensory devices. US Patent. 6814162. 2004

Qiu Z J. New technology promotes the discovery of the Tarim Natural
Gas Province. Engineering Science. 2000. 2(9): 38-41 (in Chinese) Witman G B, Wilson P, McDonough S D, et al. Single cone rock bit having inserts adapted to maintain hole gage during drilling: US Patent. 7100711. 2006

Wu X G and Liu C. Approaches to improvement of ROP in slim holes. Petroleum Drilling Techniques. 2000. 28(1): 17-19 (in Chinese)

Xia Y W, Yang G Q, Li S T, et al. Emulation model of one-cone bit drilling at well bottom. Underground Space. 2002. 22(1): 33-37 (in Chinese)

Yu K A and Yu L. The research on rock-disintegrating track of offset mono-cone bit. Oil Field Equipment. 2007. 36(1): 5-9 (in Chinese)

(Edited by Sun Yanhua) 